\title{
ПЕРСПЕКТИВИ ЗАСТОСУВАННЯ ТЕЛЕМЕДИЦИНИ В ТРАВМАТОЛОГІЇ ТА ОРТОПЕДІЇ У ТЕРНОПІЛЬСЬКІЙ ОБЛАСТІ
}

\author{
О. Л. Ковальчук, І. С. Кулянда, Ю. С. Сморщок, О. В. Думанець, В. П. Марценюк \\ ДВНЗ "Тернопільський державний медичний університет імені І. Я. Горбачевського"
}

На основі проведеного аналітичного огляду публікацій, присвячених використанню телемедицини в травматології й ортопедії, показано клінічну, економічну й організаційну ефективність можливості застосування різних телемедичних систем на всіх етапах надання ортопедо-травматологічної допомоги.

Ключові слова: телемедичні системи, телеконсультування.

\section{ПЕРСПЕКТИВЫ ПРИМЕНЕНИЯ ТЕЛЕМЕДИЦИНЫ В ТРАВМАТОЛОГИИ И ОРТОПЕДИИ В ТЕРНОПОЛЬСКОЙ ОБЛАСТИ}

\author{
А. Л. Ковальчук, И. С. Кулянда, Ю. С. Сморщок, О. В. Думанець, В. П. Марценюк \\ гВУз "Тернопольский государственный медицинский университет \\ имени И. Я. Горбачевского"
}

\begin{abstract}
На основе проведенного аналитического обзора публикаций, посвященных использованию телемедицины в травматологии и ортопедии, показано клиническую, экономическую и организационную эффективность возможности применения различных телемедицинских систем на всех этапах оказания ортопедо-травматологической помощи.
\end{abstract}

Ключевые слова: телемедицинские системы, телеконсультирование.

\section{PROSPECTS OF APPLICATION OF TELEMEDICINE IN TRAUMATOLOGY AND ORTHOPEDICS IN TERNOPIL REGION}

\author{
O. L. Kovalchuk, I. S. Kulyanda, Yu. S. Smorshchok, O. V. Dumanets, V. P. Martsenyuk \\ SHEI "Ternopil State Medical University by I. Ya. Horbachevsky"
}

\begin{abstract}
On the basis of the analytical review of publications on the use of telemedicine in traumatology and orthopedics it is shown the clinical, economic and organizational effectiveness of different possibilities of telemedicine systems in all phases of orthopedic and trauma care.
\end{abstract}

Key words: telemedicine system, teleconsultation.

Вступ. Телемедицина як галузь охорони здоров'я почала розвиватись з початку XX століття. Роком іiі народження вважається 1905, коли вперше була здійснена передача на відстань електрокардіограми, видані перші публікації з даної проблеми [12].

Телемедичні системи активно використовуються в травматології й ортопедії для діагностики, лікування, реабілітації потерпілих із травмами всіх органів і систем, а також для запобігання й лікування ортопедичних захворювань, для дистанційного (у тому числі - безперервного) навчання. Перші системні дослідження й публікації, присвячені даній тематиці, були видані на початку 1970-х років, таким чином, можна () О. Л. Ковальчук, І. С. Кулянда, Ю. С. Сморщок та ін. сказати, що телемедицина в травматології й ортопедії використовується близько 35 років. За цей період накопичений цікавий доказовий досвід, а в даний час триває стрімкий розвиток телетравматології й телеортопедії з використанням новітніх досягнень електронно- цифрових комунікацій.

3 кінця 90-х років $[11,19]$ телемедичні робочі станції на основі стандартних персональних комп'ютерів (так звана "телемедицина низької вартості") ефективно використовуються в травматології й ортопедії [17].

Синхронні телеконсультації в травматології й ортопедії освітлені в декількох публікаціях. Нами раніше представлені первинні результати комплексного ви- 
користання інтернет-додатків (електронна пошта, IPтелефонія) і мультимедійних мобільних повідомлень для ургентного телеконсультування пацієнтів 3 тяжкими травмами [3].

Доказово показана достатня клінічна ефективність і моральна задоволеність пацієнтів при первинних телеконсультаціях в ортопедії із застосуванням відеоконференцій [14]. Особливо перспективним для телемедичної діяльності в ортопедії-травматології $\epsilon$ використання систем відеоконференцзв'язку з низькими вимогами й вартістю [15], зокрема накопичений позитивний досвід застосування IP-телефонії (технологія Інтернету Voi) для проведення синхронних телеконсультацій, дистанційних лекцій і доповідей [4].

Основна частина. Для вдосконалення ортопедотравматологічної допомоги на рівні області перспективним є використання телемедицини [1]. Телемедичні системи можуть бути використані для проведення віддаленого консультування через зв'язування приймальних відділень районних лікарень і відділення травматології й невідкладної допомоги обласних медичних центрів. Завданнями таких систем є: телерадіологічне консультування, відеоконференції, телеприсутність консультанта під час лікувальних і діагностичних маніпуляцій [8]. Для цього необхідні найбільш дешеві послуги Інтернету, web-камери для відеоконференцій, персональні комп'ютери. У мережу включають кожну районну лікарню.

Європейський досвід використання такої системи показує оптимізацію транспортувань, виразний позитивний економічний ефект, клінічну ефективність.

Конкретні напрямки застосування телемедицини в травматології та ортопедії:

- системи телеконсультування на основі електронної пошти пацієнтів із травмами стопи й гомілковостопного суглоба [10];

- проведення телеконсультацій для конкретних практичних ситуацій у травматології й ортопедії [5-7];

- розроблення й впровадження телемедичних систем для курації та лікування пацієнтів 3 малою травмою (забої, розтягнення й т. д.);

\footnotetext{
Лiтература

1. Эффективность телеконсультирования по травматологии-ортопедии в рамках Областной телемедицинской сети / А. В. Анищенко, А. В. Владзимирский, В. Г. Климовицкий [и др.] // Український журнал телемедицини та медичної телематики. - 2006. - Т.4, № 2. - С. 164-170.

2. Владзимирський А. В. Лікування потерпілих із множинними і сполучними ушкодженнями на догоспітальному i
}

- телемедицина в комплексному лікуванні пацієнтів із поєднаними і множинними ушкодженнями;

- телемедичне консультування для визначення тактики лікування, в тому числі при плануванні хірургічних втручань [2];

- діагностика за оцифрованими зображеннями і використання рекомендацій віддалених експертів [18];

- оптимізація транспортування й переведення пацієнтів у спеціалізовані лікувальні установи, при цьому підвищується якість медичної допомоги та є можливість раціонального управління потоками пацієнтів [9];

- застосування телемедичних систем для постгоспітального супроводу й навчання амбулаторних пацієнтів (із сільської місцевості й віддалених районів), що перенесли складні ортопедичні операції, у тому числі ендопротезування.

Використання відеоконференцій вивчене в економічному аспекті: застосування даної технології для телеконсультування між ортопедо-травматологічними установами різного рівня, а також для дистанційної роботи з амбулаторними пацієнтами дозволяє домогтися зниження фінансових витрат системи охорони здоров'я $[13,16]$.

Телетравматологія й телеортопедія - це галузі охорони здоров'я, що динамічно розвиваються. I якщо раніше це було показано на прикладі вдосконалювання телерадіології, то в даний час такий розвиток пов'язаний із застосуванням Інтернету, бездротових i мобільних технологій, цифрових фотокамер. Окремо варто підкреслити дешевизну й широку доступність сучасних телемедичних систем для установ ортопедо-травматологічного профілю. Доказово показана клінічна, економічна й організаційна ефективність застосування різних телемедичних систем на всіх етапах надання ортопедо-травматологічної допомоги.

Висновок. Телемедицина активно використовується в травматології й ортопедії протягом останніх десятиліть. Доцільність ії застосування не викликає сумнівів, тому ця технологія повинна бути взята на озброєння медичними закладами Тернопільської області.

госпітальному етапах з використанням телемедичних систем: автореф. дис. на здобуття наукового ступеня канд. мед. наук/ А. В. Владзимирський. - Вінниця, 2003. - 20 с.

3. Владзимирский А. В. Первый опыт использования мобильных телемедицинских комплексов для телеконсультирования / Владзимирский А. В., Калиновский Д. К., Долгер В. Ф. // Мобильные телемедицинские 
комплексы. Домашняя телемедицина: матер. науч.-практ. конф .-Ростов-на-Дону, 2005. - С. 71-73.

4. Дистанционное обучение в травматологии и ортопедии - собственные разработки / В. Г. Климовицкий, А. В. Владзимирский, А. К. Рушай, В. Ю. Худобин // Травма. - 2003. Т.4, № 1. - С. 62-68.

5. Челноков А. Н. Особенности подготовки изображений для телеконсультаций в ортопедии и травматологии / А. Н. Челноков, С. М. Кутепов // Телемедицина и проблемы передачи изображений: тез. докл. третьего ежегодного Московского международного симпозиума по телемедицине. - М. : МАКС Пресс, 2000. - С. 68-69.

6. Челноков А. Н. Компьютерно-телекоммуникационные технологии в ортопедии и травматологии / А. Н. Челноков // Укр. ж. телемед. мед. телемат. -2007. - Т. 5, № 1. - С. 26-32. 7. Челноков А. Н. Телеконсультации в ортопедии и травматологии на основе web-технологий / Челноков А. Н., Кутепов С.М., Головин А.А. // Матер. науч.-практ. конф. "Лечение повреждений и заболеваний таза. Новые технологии в лечении повреждений и заболеваний опорно-двигательной системы". - Екатеринбург, 2001. - С. 123-125.

8. Armstrong I., Medical decision support for remote general practitioners using telemedicine / I. Armstrong, W. Haston // J.TelemedTelecare. - 1997. - Vol.3, № 1. -P. 27-34.

9. Bruder N. Transfer of emergency neurosurgical patients: when and how? / N. Bruder // Ann. Fr. Anesth. Reanim. - 2007.

- Vol. 26(10). - P. 873-877.

10. Evaluation of a long-distance data transmission network in foot and ankle surgery / T. Craviari, J. L. Besse, G. Curvale [et al.] // Rev. Chir. Orthop. Reparatrice. Appar. Mot. - 2003. Vol.; 89(5). - P. 433-442.
11. Point-to-point telemedicine using the ISDN / A. Darkins, N. Fisk, P. Garner, R. Wootton// J. Telemed. Telecare. - 1996. Vol. 2, Suppl 1. - P. 82-83.

12. Einthoven W. Le telecardiogramme / W. Einthoven // Archives Internationales Physiologie. - 1906. - Vol. IV P. 132-164.

13. Clinical effectiveness and cost analysis of patient referral by videoconferencing in orthopaedics / K. Harno, E. Arajarvi, T. Paavola [et al.] // J. Telemed. Telecare. 2001. - Vol. 7(4). - P. 219-225.

14. The feasibility of telemedicine for orthopaedic outpatient clinics - a randomized controlled trial / K. Haukipuro, A. Ohinmaa, I. Winblad [et al.] // J. Telemed. Telecare. 2000. Vol. 6(4). - P. 193-198.

15. Technical validation of lowcost videoconferencing systems applied in orthopaedic teleconsulting services / P. Mattioli, P. J. Klutke, F. Baruffaldi [et al.] // Comput. Methods Programs Biomed. - 1999. - Vol. 60(2). - P. 143-152.

16. A cost-minimization analysis of orthopaedic consultations using videoconferencing in comparison with conventional consulting / A. Ohinmaa, S. Vuolio, K. Haukipuro, I. Winblad // J. Telemed. Telecare. - 2002. - Vol. 8(5). - P. 283-289.

17. Desktop teleradiology in support of rural orthopedic trauma care/J. G. Reid, J. J. McGowan, M. A. Ricci, G. McFarlane// Proc AMIA Annu Fall Symp. - 1997. - P. 403-407.

18. Vladzymyrskyy A. V. The Use of Teleconsultations in the Treatment of Patients with Multiple Trauma / A. V. Vladzymyrskyy // European Journal of Trauma. - Vol. 30, № 6. - 2004. - P. 394-397.

19. Telemedicine using the internet/ L. G. Yamamoto, P. R. Elliott, M. I. Herman, T. J. Abramo // Am. J. Emerg. Med. 1996. - Vol. 14(4). - P. 416-420. 